\title{
The Origins and Interpretation of the Prebisch-Singer Thesis
}

\author{
John Toye and Richard Toye
}

The Prebisch-Singer thesis is generally taken to be the proposition that the net barter terms of trade between primary products (raw materials) and manufactures have been subject to a long-run downward trend. The publication dates of the first two works in English that expounded the thesis were nearly simultaneous. In May 1950, the English version of The Economic Development of Latin America and Its Principal Problems, by Raúl Prebisch, appeared under the UN's imprint. In the same month Hans Singer published an article, "The Distribution of Gains between Investing and Borrowing Countries," in the American Economic Review. The continuing significance of the "Prebisch-Singer thesis" is that it implies that, barring major changes in the structure of the world economy, the gains from trade will continue to be distributed unequally (and, some would add, unfairly) between nations exporting mainly primary products and those exporting mainly manufactures. Further, inequality of per capita income between these two types of countries will

Correspondence may be addressed to John Toye, Department of Economics, University of Oxford, Manor Road, Oxford OX1 3UQ, United Kingdom; e-mail: john.toye@economics.oxford. ac.uk. The authors are grateful for the generous assistance they have received from JoséAntonio Ocampo and the staff of ECLAC and ILPES in Santiago; from Aurora Tang-Keko at the UN Archive in New York; and from the United Nations Intellectual History Project and its directors, Louis Emmerij, Richard Jolly, and Tom Weiss. We especially thank Sra. Adela Prebisch for permission to quote from the Prebisch papers in her possession. Valuable comments and materials were received from James Boughton, Edgar J. Dosman, Valpy FitzGerald, James N. Miller, John Shaw, and two anonymous referees. Translations are the authors' own, and all errors remain their sole responsibility.

History of Political Economy 35:3 @ 2003 by Duke University Press. 
be increased by the growth of trade, rather than reduced. This could be, and has been, taken as an indicator of the need for both industrialization and tariff protection.

Prebisch and Singer identified two types of negative effects on primary producers' terms of trade. One effect occurs because of systematically different institutional features of product and factor markets, such as cost-plus pricing and the unionization of labor in industry. Another negative influence is that of technical progress, both from the asymmetric distribution of its fruits, but also from its asymmetric impact on future demand, favorable to that of industry while unfavorable to that of agriculture. The empirical significance of the thesis has been much disputed and continues to be controversial after more than fifty years. One recent investigation has claimed that these two effects have operated strongly in the forty years after the Second World War, and that they have indeed outweighed the positive influences on primary producers' terms of trade arising from capital accumulation and the growth of industrial production. This particular study suggested that the economic mechanisms that disfavor primary product producers, which were specified by Prebisch and Singer, have had significant impacts, even though the net secular decline of primary producers' net barter terms of trade has been found to be relatively small, at around 1 percent a year (Bloch and Sapsford 1998).

The Prebisch-Singer thesis contradicted a long tradition of contrary belief among economists. The nineteenth-century English political economists believed that the terms of trade of industrial manufactures relative to agricultural produce would tend to decline. This belief underpinned their pessimism about the sustainability of rapid population growth. That manufactures' terms of trade would decline, and that rapid population growth was therefore unsustainable, were two propositions that caused political economy to be dubbed the "dismal science." This basic framework of ideas remained remarkably stable throughout the entire century and a quarter from Robert Malthus to the early works of John Maynard Keynes. Although, by the late 1940s, this proposition was rarely stated explicitly, when Prebisch and Singer came to reverse the classical expectation of declining terms of trade for manufactures, their conclusions were immediately controversial, and are still so regarded by some today. 1

1. For an extended discussion, see Toye 2000, chap. 1. When criticizing the views of Prebisch and Singer, Jacob Viner $(1952,114)$ and Gottfried Haberler $(1988,39-40)$ both made reference to this doctrine, although without endorsing it themselves. 
Prebisch is frequently credited with having formulated the declining terms of trade thesis before Singer did. Joseph Love (1980, 58-59) claimed that "Prebisch clearly seems to have reached his position earlier than Singer." Other authors have held that Singer discovered the thesis independently and simultaneously. Cristobal Kay $(1989,32)$ wrote that "Singer ... reached his conclusions independently from Prebisch and around the same time [so that] the thesis on the deterioration in the terms of trade is known in the economic literature as the 'PrebischSinger thesis." "This second view was indeed that held by Singer himself. ${ }^{2}$ Our account of the events surrounding the United Nations Economic Commission for Latin America (ECLA) conference in Havana in May 1949 reveals that Prebisch did not discover independently that the terms of trade of primary products were secularly declining, but relied wholly on the previous work of Singer. The false impression that he had made the discovery (either first or simultaneously) was the consequence of political tensions between the developed and the underdeveloped countries that had welled up at Havana, and the way in which the top administrators of the United Nations secretariat responded to those tensions.

For at the time Prebisch and Singer made their respective contributions, both were working for the UN. Prebisch was working for ECLA in Santiago de Chile and Singer was in the Department of Economic Affairs (DEA) at UN headquarters in New York. It might seem odd that the United Nations, whose role it was to find solutions to world economic problems in order to promote peace, should be the cradle of such a controversial doctrine, one that lent itself so readily both to the economic nationalism of the underdeveloped countries and to the polemics of the Cold War. Here we tell exactly how this came about, and show how, in fact, it was the UN's own eagerness to disclaim responsibility for the doctrine that brought Prebisch into the limelight. The consequent widespread belief that Prebisch had first made the discovery in turn invested the thesis with an enhanced significance in hemispheric politics. Moreover, the UN's failed stratagem for distancing itself from Prebisch's ideas had the unintended consequence of making the world organization itself appear as a nursery of Latin American economic radicalism.

2. Singer recalled, "My discovery that Prebisch thought along lines that were so congenial to me came after I had drafted my paper." This suggests a belief that Prebisch had arrived at both the secular decline thesis and an economic explanation of it independently. John Toye and Richard Toye, interview with Singer, 12 May 2000. 


\section{Precursors of the Prebisch-Singer Thesis}

By the time of World War II, the belief had already begun to gain ground that agricultural countries had better reasons than industrial ones to be pessimistic about their economic prospects. The experience of the interwar years had appeared to demonstrate this. As the Swedish economist Gustav Cassel noted in a League of Nations study in 1927, "From 1913, a very serious dislocation of relative prices has taken place in the exchange of goods between Europe and the colonial world" (Love 1991, 2). The world crisis of 1929 drew further attention to such questions, particularly in Latin America. As Sanford A. Mosk noted in 1944, when reviewing trends in the continent's economic thought, "The relatively unfavourable price position for raw materials and foodstuffs that prevailed in the interwar period, and especially during the depression of the 1930s, profoundly affected the outlook of Latin Americans" (Whitaker 1945, 143). This perception had already led to the claim, which had become increasingly commonplace in the region, that primary product exporters were at a disadvantage in international trade, compared to exporters of industrial products (see, for example, Simonsen 1939, 15).

Primary-commodity exporting countries like Brazil and Argentina were starting to see their future economic security in terms of promoting industrialization. The war years intensified such resolve, and also raised confidence that an industrialization drive, particularly if organized by the government, could succeed. ${ }^{3}$ Charles Kindleberger (1943b, 349) bolstered this conviction, by suggesting as early as 1943 that industrialization was the path of the future, invoking Engel's law of demand against the classical orthodoxy on the terms of trade. In that year he wrote that "inexorably ... the terms of trade move against agricultural and raw material countries as the world's standard of living increases (except in time of war) and as Engel's law of consumption operates." It is well established that another of Kindleberger's articles (1943a), with a similar pro-industrialization message, based both on the differing elasticities of demand for primary and manufactured products and on the special "institutional organisation of production in industry," was read by Prebisch. ${ }^{4}$

3. Central European thinkers had advocated state-led industrialization in the 1920s on the grounds of unequal exchange between groups of nations at the center and the periphery of the world economy. This idea, particularly as used by Werner Sombart, was introduced to Latin America by Ernest Friedrich Wagermann in his Evolución y ritmo de la economía mundial (1933). See FitzGerald 1994, 94-95.

4. See the discussion in Love 1994, 421, 421 n. 84. 
Although many North American neoclassical trade theorists reacted very critically to the Prebisch-Singer thesis in the 1950s, others among them were not immune from this emerging current of opinion. Paul Samuelson has been frequently caricatured as the high priest of an over-abstract and ideological neoclassical orthodoxy. ${ }^{5}$ Yet, remarkably, in 1948 he himself asserted the tendency of the terms of trade of primary producers to decline. He wrote at the end of his famous article on the equalization of factor prices as a result of trade: "[Now] the terms of trade are abnormally favourable to agricultural production. Without venturing on rash prophecy, one can venture scepticism that this abnormal trend of the terms of trade, counter to historical drift, will continue" (Samuelson 1948, 183-84; emphasis added). Up to this time, however, anticipation of the Prebisch-Singer thesis remained in the category of remarks en passant, or obiter dicta made during the course of the demonstration of other, quite distinct, propositions. It is nevertheless surprising that one of these stray anticipatory remarks was from the pen of Samuelson, the economist who was later set up as the archenemy of structuralism, and that this fact has been hitherto generally overlooked.

\section{Prebisch's Intellectual Formation}

Prebisch was born in Argentina in 1901. By the time he entered the UN, he had had a long career of public service in his home country, culminating in his tenure as head of its central bank. He was forced to resign this post in 1943, as a result of a Perónist stratagem, and went on to spend five years at the University of Buenos Aires, struggling as an isolated intellectual to write a book, titled Money and the Rhythm of Economic Activity, that was never completed or published. ${ }^{6} \mathrm{He}$ later recalled being offered the post of executive secretary to ECLA just after it was established in February 1948 (Love 1994, 414; Magariños 1991, 128). He said that at this time he "emphatically refused." His motives were that he did not want to give up his university post, and also that he doubted that an international organization would take seriously the point of view of underdeveloped countries (Magariños 1991, 128-29). Gustavo Martínez Cabañas, a Mexican, was appointed executive secretary instead, but he

5. See, for example, Cardoso [1980] 1984, 23, and Furtado 1987, 101. This view is also to be found in Love 1980, 63, which was endorsed by Kay $(1989,5)$ and Love $(1994,422)$.

6. For an exposition of Prebisch's outline of this planned book, drafted in OctoberDecember 1943, see Dosman 2001. 
only took up his post in January 1949. Thus, Eugenio Castillo, a Cuban, who was his deputy, was in effect running the commission before this date.

Later in 1948, the Argentine government barred Prebisch from teaching (Ferrer 1990). He definitively resigned his university post in November and began to consider working outside the country. ${ }^{7}$ The managing director of the International Monetary Fund (IMF), Camille Gutt, and his deputy Edward M. Bernstein visited Buenos Aires in November 1948 and offered Prebisch a senior post in the Fund. This followed up an offer of a short-term assignment in Washington, made in the previous January. When in late December 1948 Gutt cabled that the terms of the offer would have to be changed, Prebisch replied that he was "quite willing to join the Fund on the basis proposed." However, the executive board of the IMF decided not to proceed. The U.S. government had reversed its favorable position on the appointment, because it wanted to improve relations with Perón, and Brazil also voted against Prebisch. ${ }^{8}$ On 11 March 1949 Maurice L. Parsons, director of operations at the IMF, wrote an extremely apologetic letter to Prebisch, expressing personal regret at the Fund's failure to secure his services. ${ }^{9}$

Simultaneously with Gutt's approach, Eugenio Castillo of ECLA asked Prebisch for help in preparing an economic survey of Latin America. Prebisch was at first unwilling to commit himself, because he much preferred to accept the IMF offer. ${ }^{10}$ It was only on 10 January 1949 that he agreed to work for ECLA as a consultant on a short-term contract. ${ }^{11}$ His allotted tasks were to coordinate and pull together in final form the commission's planned Economic Survey of Latin America, which was to be presented to the ECLA conference in Havana in May 1949. Up to this point, he had made only one public contribution on the terms of trade issue that needs to be noted. The depression of the 1930s

7. Letter from R. Prebisch to E. Castillo, 23 November 1948, Prebisch Papers (in the possession of Sra. Prebisch).

8. This episode is examined in more detail in Dosman 2001.

9. Letter from J. Marquez to R. Prebisch, 23 January 1948; letter from R. Prebisch to E. Bernstein, 17 December 1948; letter from M. L. Parsons to Prebisch, 11 March 1949, Prebisch Papers. James Boughton, currently in-house historian of the IMF, passed on to us this comment from Jacques Polak: "I have absolutely no recollection of any such offer, but it would not be wholly out of character for Bernstein to make it without discussing it with me (a mere division chief at the time)."

10. Letter from R. Prebisch to E. Castillo, 23 November 1948; letter from Francisco Coire to R. Prebisch, 24 December 1948, Prebisch Papers.

11. Letter from R. Prebisch to E. Castillo, 10 January 1949, Prebisch Papers. 
had created exceptionally unfavorable terms of trade for exporters who relied on agricultural products and raw materials. By 1932, export prices had fallen in Argentina to 37 percent of what they had been in 1928, and her net barter terms of trade were down to 68 from a 1928 value of 100, indicating a less precipitous fall of import prices (Thorp 1998, 105, table 4.1). Prebisch had documented this when was he was director of research at the National Bank of Argentina. He published an article in 1934 arguing that "it is a well-known fact that agricultural prices have fallen more profoundly than those of manufactured articles," and that Argentina had to export 73 percent more than before the depression to obtain the same quantity of manufactured imports (Prebisch [1934] 1991, 341). However, Prebisch was merely noting a fact, and did not provide any theoretical analysis of it (Magariños 1991, 63-64). He saw it as a feature of depression economics, that is, as a short-run cyclical problem. He believed that the remedy was to be found in expansionist economic policies, not, as the Prebisch-Singer thesis would later imply, in major changes in the structure of the international economy. 12

Prebisch attended the World Economic Conference in 1933, and The Means to Prosperity, which Keynes published at this time, powerfully affected his hitherto orthodox thinking (Magariños 1991, 100). ${ }^{13}$ His views must also be seen in the context of the emerging current of opinion in Latin America, previously mentioned, that asserted that primary producing nations were at a particular disadvantage in relation to industrialized countries. Before 1949, Prebisch played only a marginal role in promoting this discourse. During his years at the University of Buenos Aires, the focus of Prebisch's research was on the international business cycle, in the tradition of Wesley Mitchell (1927) and Joseph Schumpeter (1939), and on the prospects for the use of Keynesian countercyclical policies. ${ }^{14}$ It was in this context that he first used the terms cyclical center and periphery. ${ }^{15}$ In his introductory class in 1945, he referred to the

12. He believed that "the normal oscillation in the economic life of an agrarian country can be supported by the monetary system, if that system is in good condition" (Prebisch 1991, 2:566).

13. In March 1933, the Times of London published four articles by Keynes, which, expanded by an introductory and concluding chapter, were published in pamphlet form as The Means to Prosperity. The slightly enlarged American edition is in Keynes 1973-89, 9:335-66.

14. "Prebisch's main concern was the international propagation of the business cycle," according to Furtado (Kay 1989, 9).

15. In 1980, Prebisch did not recollect Sombart's earlier use of these terms, according to Love $(1980,63)$. However, FitzGerald $(1994,95)$ thinks that it is "most unlikely" that Prebisch "was unaware of the origins of the contemporary center-periphery concept." 
maintenance of full employment as the supreme responsibility of the United States, as "the monetary and economic center of the world," although he did not use the term periphery in this particular lecture (Prebisch 1945, 529). In an intervention in a meeting of American central bankers in 1946, he used both terms together, to argue that the responsibilities of the "cyclical center" had been too much emphasized, and that the "countries of the periphery" themselves must resolve disequilibria with internal causes (Prebisch 1946, 163-64). ${ }^{16}$ In 1948, he reverted to his previous (1945) theme that the main responsibility for carrying out a countercyclical investment policy rested with the cyclical centers (Prebisch 1948b, 161).

A glimpse of Prebisch's overall research program at this time can be found in a letter to Eugenio Gudin.

I believe that the cycle is the typical form of growth of the capitalist economy and that this is subject to certain laws of motion, very distinct from the laws of equilibrium. In these laws of motion the disparity between the period of the productive process and the period of the circulation of the incomes therefrom holds a fundamental importance. So I have tried to introduce systematically the concept of time into economic theory and also that of space, which in the ultimate instance resolves itself into a problem of time. It is precisely the concept of space that has led me to study the movement in the center and the periphery, not with the aim of establishing formal distinctions but to point out transcendent functional differences. ${ }^{17}$

He also believed that, more generally, economic theory required "renovation" in order to bring it nearer to reality. 18

Love $(1980,57)$ has stated, on the evidence of a transcript of lectures given by Prebisch in 1948, that "Prebisch implicitly already had his opinions about the direction of Latin America's long-range terms of trade, since he had argued in the classroom in 1948 that the benefits of technological progress were absorbed by the center." Furthermore,

16. Prebisch did not define cyclical center, but we infer from the context that he meant those economies from which major depressions that can affect the rest of the world originate. In 1945, this could have only referred to the economy of the United States.

17. Letter from R. Prebisch to Eugenio Gudin, 20 December 1948, original in Spanish, Prebisch Papers.

18. Letter from R. Prebisch to E. Castillo, 23 November 1948, original in Spanish, Prebisch Papers. 
"Prebisch had formulated the elements of his thesis before the appearance, in 1949, of the empirical base on which the thesis rested in its first published form-the UN study, Relative Prices" (Love 1980, 65; for more on both statements, see Love 1994, 417-18). Part of Prebisch's 1948 lectures did discuss the case where one country (call it A) experiences technical progress in some of its economic activities (manufacturing) and then trades with another country (B) that does not experience technical progress. Prebisch argued that country A can retain for itself the fruit of technical progress, and specifically asserted that, historically, both Great Britain and the United States had done so. His argument about the conditions under which this happened was, however, confused, and in the course of it he did not actually use the terms center and periphery (Prebisch 1948a, 87-98). The argument is not sufficiently well specified to permit the claim that it could have only one logical implication for the net barter terms of trade of country B. In the context, one would certainly not have been surprised if Prebisch had asserted that country B's terms of trade would continuously decline, but the crucial point is that he did not do so.

Before he became aware of the UN data, Prebisch never explicitly stated the thesis that Latin America's terms of trade had been subject to long-term decline, as opposed to the sharp short-term decline that he noted in 1934.19 Nor does Love claim that he did; he claims only that "he implicitly already had his opinions." Prebisch had clearly by 1948 arrived at the idea that the fruits of technical progress could be distributed unequally, an idea that he would later refine and integrate into his explanation of the secular decline phenomenon. But his chief concern at the time was still the study of the business cycle, as the typical form of growth of the capitalist economy; of the secular decline phenomenon itself, he remained unaware. The following year, however, he publicly stated that secular decline was taking place. To understand how this happened, why priority of discovery was subsequently claimed for Prebisch and how this priority claim then affected the meaning that contemporaries attached to the thesis, it is necessary to trace a complex sequence of political events and administrative decisions. We start with Singer's arrival at the United Nations.

19. Prebisch did, however, use the phrase "persistent fall in the international prices of our exports" in the 1943 outline of his unpublished book, according to Dosman 2001. 


\section{Singer Starts Work on the Terms of Trade}

Singer, the younger of the two, came to the UN via a rather different route than Prebisch, although his story also included escape from persecution. He was born in the German Rhineland in 1910, and studied under Joseph Schumpeter in his Bonn period. After the Nazi seizure of power in 1933, Schumpeter used his contacts with Keynes to place Singer in a scholarship to undertake a Ph.D., on secular trends in land values, at Cambridge. In 1940, the Nazis put Singer on their "Special Wanted List GB," to be arrested by the Gestapo in the event of a German invasion of Britain (Schellenberg 2000, 242). Singer's doctoral work led him to wartime employment in the Ministry of Town and Country Planning, but he intended to return to academia after the war. However, David Owen, the head of the UN DEA, invited Singer to join the United Nations. In 1946, Owen sent a formal request to this effect to Glasgow University, Singer's employer, and Singer quite reluctantly agreed to go on a twoyear leave of absence, one that ultimately turned into a twenty-two-year period of UN service. ${ }^{20}$

He arrived in New York in April 1947, knowing there only Michal Kalecki and Sidney Dell, while Owen was absent at the international trade negotiations in Geneva. He found himself unrestricted in his choice of research subject and immediately began to work on trade problems, although his previous economic background had not been specifically related to trade issues. Singer later recalled:

A strong influence among the early colleagues in the United Nations was that of Folke Hilgerdt, the Swedish economist who had already shaped the League of Nations publications on the Network of World Trade. Working with him was Carl Major Wright, a Danish economist who was particularly interested in the relationship of primary commodity prices to trade cycles and economic growth in industrial countries. Two other staff members in the trade section were Walter Chudson (United States) and Percy Judd (Australia), the latter being very expert in the economics and details of commodity agreements. Discussions with these four must have drawn my attention quickly to problems of terms of trade. (Singer 1984, 280)

20. "I was not very happy. . . . I went-though I really didn't want to go. For me that was a step down and I was quite looking forward to settling down in Glasgow." Hans Singer interview with Richard Jolly, 13 October 1995. 
The official stimulus for this work was the report of first session of the UN Sub-Commission on Economic Development. The members of the subcommission were elected on 5 June 1947. Considering problems of economic development in underdeveloped countries, the report of its first session contained the following comment:

The recent rise in the prices of capital goods and transport services has made the task of economic development particularly difficult in the case of the under-developed and the least developed countries. The Sub-Commission therefore considers it important that a careful study be made of the prices of capital goods and of the relative trends of such prices and of prices of primary products, so that it may be in a position to make appropriate recommendations concerning the problem. (United Nations 1949b, 1)

As a result, the UN secretariat began to study the terms of trade. The task was to address a short-term problem. The original objective was not to discover the historical drift of the terms of trade, or what had happened over the long run. The problem was that, during the war, a number of underdeveloped countries had run export surpluses that they subsequently wished to use to import capital goods for development. In the interval, the prices of capital goods had risen, so the export surpluses were worth less in terms of imports than they had been when they were earned. This provoked the question of whether underdeveloped countries' terms of trade could be expected to continue to deteriorate in this way, and the implication of this for their economic development. This was the official purpose of the research on which Singer embarked.

Singer worked under the general guidance of Folke Hilgerdt, who, as director of the UN Statistical Office, provided a key link between its work and the statistical work of the former League of Nations on trade. Hilgerdt was the principal author of a series of studies on commerce and commercial policy, which the Economic, Financial, and Transit Department of the league issued as part of its program of studies on postwar problems. The final volume, Industrialization and Foreign Trade (1945), included an appendix on the statistics of international trade between 1871 and 1938. Appendix tables 7 and 8, when read in conjunction, show that between those dates the price index of manufactured articles fell significantly less than that of primary products. However, nothing was made of this in the summary of findings of the report. The statistical base for this study was available for Singer's research (League 
of Nations 1945, 154-67, 116-21). Moreover, Hilgerdt expressed puzzlement to Singer over the behavior of the British terms of trade data (Singer 1991, 9).

In his Ph.D. dissertation, Singer had studied problems of the very long run. Unlike Hilgerdt and Wright, he was not interested in cyclical effects on the terms of trade produced by booms and slumps in industrial countries. He, being more influenced by Gunnar Myrdal, focused on structural differences between industrial and nonindustrial countries, and their long-term effect on the evolution of the terms of trade between them. His overarching concern was that of distributive justice. His question was not whether gains from trade existed, which he did not doubt, but the "fairness" of the distribution of those gains between the countries that traded. If there were power differences between countriesdisparities in market power or in technological power-did trade, and changes in the terms on which it was conducted, become a mechanism of "un-equalizing" growth between countries globally? His interest in the commodity terms of trade was thus a derivative of the larger question of worldwide un-equalizing growth. That question itself was framed by the historical context of the process of decolonization, as in the transition of India to independence in 1947. Were the colonial powers, he wondered, willing to relinquish control of their colonies only because the international economic system would now spontaneously generate the same world division of labor that had previously been enforced militarily and politically?

The results of Singer's research were presented in a UN document titled Post-war Price Relations between Under-developed and Industrialized Countries that appeared on 23 February 1949 (United Nations 1949b). ${ }^{21}$ This was an advance version of the terms of trade study, subject to final checking of the data, which was made available to the SubCommission on Economic Development. The document was retitled Relative Prices of Exports and Imports of Under-developed Countries for its general circulation in late 1949, with the subtitle A Study of Post-war Terms of Trade between Under-developed and Industrialized Countries. It was a remarkable piece of work. It included an attempt to see what historical statistics indicated about the long-term trend in the agriculture versus manufactures terms of trade, although its origin lay in developing countries' concern with future relative prices as industrialization

21. It should be noted that this is available in the UNOG Library in Geneva, but not in the Dag Hammarskjöld Library at the United Nations in New York. 
Table 1 Ratios of U.K. Imports to Exports, 1876-1948 (1938 = 100)

\begin{tabular}{lcc}
\hline Period (or year) & Current Year Weights & Board of Trade Index \\
\hline $1876-80$ & 163 & \\
$1881-85$ & 167 & \\
$1886-90$ & 157 & \\
$1891-95$ & 147 & \\
$1896-1900$ & 142 & \\
$1901-5$ & 138 & \\
$1906-10$ & 140 & 143 \\
1913 & 137 & 101 \\
1921 & 93 & 96 \\
1933 & 98 & 100 \\
1938 & 100 & 108 \\
1946 & & 117 \\
1948 & & \\
\hline
\end{tabular}

drives gathered pace. It showed that the terms of trade of underdeveloped countries had improved between 1938 and 1946-48. This recent improvement was, however, placed in a much longer historical perspective, showing that between 1876 and 1948 they had seriously deteriorated. The historical section contained the report's most dramatic finding. It was that "from the latter part of the nineteenth century to the eve of the Second World War, a period of well over half a century, there was a secular downward trend in the prices of primary goods relative to the prices of manufactured goods" (United Nations 1949c, 7). Singer recalled that he and Hilgerdt together spotted this trend in the data. ${ }^{22}$ The cumulative effect of secular decline was calculated to be substantial.

By 1938, the relative prices of primary goods had deteriorated by about 50 points, or one-third, since (the 1870 s) and by about 40 points, somewhat less than 30 per cent, since 1913. (23)

The statistical evidence for this downward trend was given in table 5 of the report, of which a simplified version is presented in our table 1.

What was the significance of this secular decline? The report was careful not to suggest that if a country's terms of trade improved, its welfare necessarily increased. It might or might not, depending on the circumstances in which the rise in export prices takes place. If the price rise was a result of a failure of supply, it might not leave the exporting 
country better off. Nevertheless, in general, an improvement in terms of trade would increase the availability of resources for development. A secular decline for underdeveloped countries meant a loss of capacity to absorb foreign financing for development, and thus to respond to the "added incentive towards industrialization" (United Nations 1949c, $16,127)$. A further, far more controversial, implication was also drawn, that "the under-developed helped to maintain . . . a rising standard of living in the industrialized countries, without receiving, in the price of their own products, a corresponding equivalent contribution towards their own standards of living" (126). This carried a clear message of historical injustice, and this message was, as we shall see, very shortly to be rejected by the subcommission. ${ }^{23}$

Singer had already announced this message in a seminar that he gave to the graduate faculty of the New School of Social Research, New York, on 23 December 1948. There he said that "Marxist analysis, in which rising standards of living for given groups and sections are somehow held to be compatible with general deterioration and impoverishment, is much truer for the international scene than it is for the domestic." He attributed the growing inequality in the distribution of world income to the change in price relations between primary materials and manufactured goods (Singer 1949, 2-3). ${ }^{24}$

\section{How Prebisch Made Use of the Singer Study}

The creation of ECLA had resulted from "an act of audacity" by Hernán Santa Cruz, the Chilean representative on the UN Economic and Social Council (ECOSOC) (Magariños 1991, 136). He felt that Latin America was being unjustly ignored by the great powers, and conceived the idea of a UN commission to deal with the region's economic and social problems, on the model of the UN Economic Commission for Europe. Receiving no orders to the contrary from his government, he took the initiative and submitted his proposal as an item for the UN ECOSOC agenda (Santa Cruz 1995). On 1 August 1947, he formally introduced his resolution to a meeting of ECOSOC. Although the United States and other industrial countries much disliked the idea, their opposition was

23. "I thought if you look at foreign trade from the point of view of the poor countries, exporters of primary products, what does it look like? And it appears an unequal system that is weighted against them." Hans Singer interview with Richard Jolly, 11 October 1995.

24. We are most grateful to John Shaw for drawing this document to our attention. 
not sufficiently determined, and in early 1948 ECLA duly came into being. 25

One of the justifications for establishing ECLA was to provide better information about economic conditions in the region as a whole. ${ }^{26}$ Originally, it was assumed that this could be achieved merely by collating statistics submitted by the individual Latin American governments. When most governments failed to provide the required figures, the commission realized that it would have to collect them itself, for the first Economic Survey of Latin America, which was due to be presented to the ECLA conference in Havana in May 1949. Additionally, the first ECLA conference, in June 1948, had passed a resolution asking for the preparation of "a study of the movements of import and export prices, the determining factors of such movements, and the consequences thereof on the balance of payments." 27 By the autumn of 1948 it became clear that these tasks were beyond the unaided capacity of the ECLA office in Santiago. 28 The weak statistical abilities of the fledgling commission thus form an important background factor in the preparations for Havana.

Accordingly, Louis Shapiro, a statistician in the Department of Economic Affairs, was sent from the UN office in New York on deputation to Santiago for three months between December 1948 and March 1949, in order to organize these tasks. It was during this mission that he received from Hans Singer the provisional draft of his study on the terms of trade. From Santiago, Shapiro wrote Singer a letter of acknowledgment dated 5 January 1949:

Thank you most kindly for your letter of 17th December 1948, and for the enclosed provisional draft of the General Part of your study

25. On 25 February 1948, a motion establishing the new body was passed, with no votes against, and four abstentions (Byelorussia, Canada, the United States, and the USSR). As Leroy Stinebower, who was present on behalf of the United States, later recalled, "The forces of globalism were being overwhelmed - or at least over shouted - at that moment by a lot of regionalism stuff. . . . even in my worst dreams I didn't think that regionalism would go as far as it's gone in this world." Leroy Stinebower Oral History, 9 June 1974, pp. 65-66, Harry S. Truman Library, Independence, Missouri.

26. "The Economic Commission for Latin America . . . shall arrange for such surveys, investigations and studies to be made of the economic and technical problems (of the region) as it may deem proper and participate in the same." Extract from the Official Records of the UN Economic and Social Council, second year, fifth session, proposal addressed to the secretarygeneral by the delegation of Chile, document E/468, 12 July 1947.

27. Resolution of the first session of ECLA, 24 June 1948, UN document no. E/CN.12/71

28. Celso Furtado (1987, 54-56) tells the story of how he, as a new recruit to ECLA, was urged by the executive secretary, Martínez Cabañas, to bring to Santiago as many documents on Brazil as possible for the purpose of strengthening the survey. 
on the Terms of Trade. I have also received via the pouch drafts of the country sections of Terms of Trade for which many thanks. I have read quite carefully the General Part and find it most admirable. Your note on the methodology and the statistical "caveats" are especially noteworthy. I have passed this on to Mr Castillo who also agrees that this is an excellent piece of work. ECLA plans to include a substantial statistical section on the terms of trade in the forthcoming Survey of Latin America and will, with your permission and clearance, rely heavily on your data. 29

The International Monetary Fund (IMF) had also promised to send ECLA a study on the terms of trade. Shapiro reported to Singer that he had not been encouraged by its progress and content when he had visited Washington, but indicated that ECLA would study carefully the IMF work in conjunction with Singer's own, and that Castillo was "in complete agreement with this procedure." Shapiro also asked to be sent revised drafts of the "general part" and of the Latin American country sections as they were completed. ${ }^{30}$

A version of the IMF study was available by March 1949, although it was not published as an IMF staff paper until the following year. It dealt mainly with the period 1938 to 1946 and included no data at all from before 1925. It found that the terms of trade of Latin America as a whole had improved between 1938 and 1946. The IMF study made no comment, however, on the UN study's thesis of secular decline since the 1870s (Ahumada and Nataf 1950). Nevertheless, the IMF study left a larger imprint on the Economic Survey of Latin America than did Singer's study. In the event, the survey's one mention of secular decline in the terms of trade of primary producers was extremely brief (United Nations 1949a, xix, 216-20), and almost certainly inserted after Prebisch had completed and circulated the document that became The Economic Development of Latin America (Prebisch 1950). Thus Singer's work did not create any real impact in ECLA until it had reached the hands of Prebisch himself.

How did it get there? The second route by which the Singer study was transmitted to Latin America was via Martínez Cabañas. Before arriving

29. Letter from L. A. Shapiro to H. W. Singer, 5 January 1949, UN Archive, New York. As the reader will recall, Eugenio Castillo ("Mr Castillo") was the deputy executive secretary of ECLA.

30. Letter from L. A. Shapiro to H. W. Singer, 5 January 1949, UN Archive, New York. 
at ECLA, Prebisch had gone to Mexico to deliver lectures at the Universidad Nacional Autónoma de México, arriving in mid-February. ${ }^{31}$ In late February or early March, Francisco Coire, head of the Latin American section of the DEA in New York, sent him both the Singer study and the IMF study. ${ }^{32}$ On 5 March, Martínez Cabañas wrote from New York to Prebisch in Mexico drawing both these works to his attention.

Our friend Coire has informed me that he has already sent you two studies on questions relating to foreign trade: one drawn up by $\mathrm{Sr}$. Singer which is to be found under the number E/CN.1/Sub3/W5 with the title Post-war Price Relations in the Trade between Undeveloped and Industrialised Countries. . . . the other study is from the International Fund and refers more concretely to the theme of Foreign Trade.

He reported that the conclusions of the Singer study had been "much debated." He pointed out to Prebisch that both studies had a bearing on a problem - the terms of trade-which was "one of the most important of those that will be treated in the general study that we are going to present at the Havana Conference." He repeated to Prebisch that he (i.e., Prebisch) would have the final responsibility for drawing up that report. 33 Thus it was the Martínez Cabañas visit to New York, rather than the early version seen and favorably commented upon by Castillo, that made the effective link from Singer to Prebisch.

Prebisch must have arrived in Santiago soon after 9 March, when he had received a telegram from Castillo asking him to come immediately. ${ }^{34}$ This was shortly after Shapiro's return to New York. It seems that before long Prebisch turned his mind to the question of the terms of trade, as one would have expected, given the strong urgings of Martínez Cabañas. Then, on 1 April 1949, Prebisch sent a request, through Castillo, to Shapiro in New York for three types of additional data-additional, that is, to the data contained in United Nations 1949b, which it seems clear that Prebisch had now read. 35 Castillo did not explain the reasons behind Prebisch's request, but the wish for data starting in 1873, the year the British

31. Letter from E. Castillo to R. Prebisch, 16 February 1949, Prebisch Papers.

32. Letter from G. Martínez Cabañas to R. Prebisch, 5 March 1949, original in Spanish; F. Coire to R. Prebisch, 8 April 1949, Prebisch Papers.

33. Letter from G. Martínez Cabañas to R. Prebisch, 5 March 1949, original in Spanish, Prebisch Papers.

34. Telegram from E. Castillo to R. Prebisch, 9 March 1949, Prebisch Papers.

35. "1. Wholesale prices indices of the United Kingdom from 1873 to 1947, divided, if possible, into indices of manufactured products and raw materials. 2. Price indices for exports 
Great Depression began, suggests an interest in the respective experience of the United Kingdom and the United States as "cyclical centers," a problem he returned to in the Economic Survey of Latin America in the following year (United Nations 1951). ${ }^{36}$ Prebisch was also anxious to see an early draft of Kalecki's study on inflation and Coire's draft of part 2 of the survey. 37

Celso Furtado, an ECLA staff member, later recalled how Prebisch initially worked very much on his own, and then a month after his arrival (presumably in mid-April), circulated within ECLA a first draft of an introduction to the Economic Survey. Furtado described this draft as a digest (Fr. mouture) of the papers that Prebisch had brought with him from Buenos Aires. The subjects covered were disequilibria in the balance of payments, the declining U.S. import coefficient, capital controls, low saving leading to domestic inflation, and the limits of industrialization. Thus, the first draft of Prebisch's introduction did not cover the terms of trade, according to Furtado's account of it. ${ }^{38} \mathrm{He}$ did employ his "center-periphery" terminology and acknowledged the importance of industrialization. It seemed to Furtado $(1987,65)$ that "this text contained extremely interesting ideas, but the author placed himself on the defensive."

Furtado (1987, 65-66) recalled as follows:

We had hardly started to discuss the document, when it was suddenly discarded, without any explanation. Prebisch's new text was not circulated for discussion. I suppose that it was ready on the eve of the Havana Conference, because it was sent to us typewritten, in its final version, shortly before we left. It was a much longer text including tables and charts. The tone had changed, now it was a manifesto urging Latin American countries to launch into industrialisation. One could discover there a definite taste for a polished and polemical style.

This account suggests that mid-April 1949 was the decisive point in Prebisch's drafting process. At this point, however, Prebisch had not had any

\footnotetext{
and for imports for the United Kingdom and for the United States for the same period. 3. United States national income from 1910 to 1929."

36. Letter from E. Castillo to L. A. Shapiro, 1 April 1949, UN Archive, New York.

37. Letter from E. Castillo to F. Coire, 1 April 1949, UN Archive, New York.

38. This first draft does not appear to have survived among the manuscript papers and correspondence currently in the possession of Sra. Prebisch, although these have not been fully cataloged.
} 
reply to Castillo's data requests of 1 April. The reply was not sent until 27 April, and it was the third channel of transmission of Singer's study. Shapiro scribbled the words "in Singer Paper" over Prebisch's second request, and this was the only one he could fulfill (apart from the U.S. national income figures for 1910-29). ${ }^{39}$ However, it is almost certain that this data arrived too late to have any influence on Prebisch's introduction. There are no traces of it in the finished product, which, as far as the terms of trade are concerned, contains only the U.K. part of the data in table 5 of United Nations 1949b, slightly reformulated. Prebisch spliced one of the U.K. series down to 1913 with another of the U.K. series thereafter, and put them on a base of $1876-80=100$, instead of $1938=100$ as originally (Spraos 1980, 107; 107 n. 2; 111-12, table 1 and the singleasterisk note).

If it was not the arrival of additional information, then, what was it that stimulated Prebisch to abandon his original draft? This remains unclear. Around this time Prebisch received Coire's draft of part 2 of the Economic Survey. Only one chapter of this was used in the finished product (United Nations 1949a, 247 n. 1), and is now apparently lost, but from Coire's remarks to Prebisch it seems clear that it had a strong proindustrialization message and had a polemical tone in places. 40 This, or perhaps further reflection on the implications of the Singer study, may have given Prebisch extra inspiration.

Prebisch dealt with the whole issue of secular decline extremely briefly in his new text. The introduction that summarizes its argument does not even mention the terms of trade. The subject is then handled in the first three pages of chapter 2. Prebisch's only comment on the terms of trade statistics, albeit one that was to resonate through the subsequent critical debate, was that "it is regrettable that the price indexes do not reflect the differences in quality of finished products" (Prebisch 1950, 8 ). This short but crucial section powerfully reinforced his other main arguments - that the international division of labor was an "out-dated schema," and that "industrialization is the only means by which the Latin-American countries may fully obtain the advantages of technical progress" (Prebisch 1950, 1, 16).

39. Letter from E. Castillo to L. A. Shapiro, 1 April 1949, and Shapiro's reply, 27 April 1949, UN Archive, New York.

40. Letter from F. Coire to R. Prebisch, 8 April 1949, Prebisch Papers. 


\section{Anonymity of Authorship in the UN}

As has been seen, it is not possible to sustain the claim that Prebisch was the first to discover the phenomenon of the secular decline in the terms of trade of primary producers. On the ground that Prebisch's contribution was complete by May 1949, while Singer's paper was not presented to the American Economic Association meeting until December 1949, Love (1980, 58-59) concluded that "Prebisch clearly seems to have reached his position earlier than Singer." This was faulty reasoning, given Singer's authorship of the UN study, something of which Love does not seem to have been aware. John Spraos has commented on the general lack of awareness of Singer's authorship, and he correctly attributed it to the UN's rule that authors of its publications remain anonymous. ${ }^{41}$

Anonymity is indeed the general fate of the authors of UN publications. ${ }^{42}$ Since the UN has employed many distinguished economists, it has become a standard task for their biographers to try to disentangle those sections of UN publications that they authored. ${ }^{43}$ What is odd in the present case is not that Singer's authorship should have been invisible, but that Prebisch's should have been visible. What was originally intended to be the introduction to the ECLA survey for 1948 eventually appeared under Prebisch's name as The Economic Development of Latin America and Its Principal Problems. Had the piece been retained as the introduction to the survey, its author would, like Singer, have remained anonymous. In the event, however, it appeared as a separate UN publication, but with the author personally identified. The UN rule of anonymity was applied to Singer and Prebisch asymmetrically. This came about in the following way.

The Sub-Commission on Economic Development held its third session, from 21 March to 11 April 1949. It discussed Singer's study, Postwar Price Relations. It accepted, somewhat grudgingly, the statistical

41. "It is an interesting fact, perhaps not widely known because of the anonymity of UN staff publications, that the principal author [of Post-war Price Relations and Relative Prices] was Hans Singer who became the second twin in the 'Prebisch-Singer thesis' through a subsequent signed article" (Spraos 1980, 107 n. 3).

42. Alexander Loveday, who directed the economic research of the League of Nations, wrote critically of "the rigidity of their [the UN's] anonymity rule," which he thought hampered the employment of temporary experts. See Loveday 1956, 296.

43. See, for example, the efforts of Jerzy Osiatynski to identify the UN writings of Michal Kalecki, in Osiatynski 1990-97, 7:552-75. 
evidence, but rejected the lessons that had been drawn from it. Its report said the following:

The Sub-Commission is constrained to point out that the study under review contains certain conclusions in regard to the price relationship between developed and under-developed countries which, in its opinion, do not represent a correct picture of the actual position. As a result of the discussion, the Sub-Commission agreed that while the document contained an adequate study of relative price trends of primary commodities and manufactured goods, it was necessary to broaden the scope of the study into that of the terms of trade between underdeveloped and industrialized countries, including prices and quantities traded, and in extending it, to cover the most recent movements in these fields. (United Nations 1949d, 12)

The most controversial of the suggestions that Singer had made in interpreting his findings, was, of course, that underdeveloped countries were helping to maintain a rising standard of living in industrialized countries without receiving any equivalent compensation. This was potentially politically explosive. While it appealed to the underdeveloped countries, it appealed not at all to the developed. It seems plausible to suggest that the subcommission used the (acknowledged) fact that the picture presented by the study was in some ways incomplete as an excuse for disclaiming its radical conclusions.

It is probable, given the slow rate of circulation of UN documents, that Prebisch was not aware of the subcommission's report when he wrote. Be that as it may, in the final version of his introduction, he repeated the implication to which it seems the subcommission had objected by quoting the relevant passage from Singer's study (Prebisch 1950, $10 \mathrm{n}$. 3 ). Worse, by using his terminology of center and periphery, he further dramatized it:

The enormous benefits that derive from increased productivity have not reached the periphery in a measure comparable to that obtained by the peoples of the great industrial countries. Hence, the outstanding differences between the standards of living of the masses of the former and the latter and the manifest discrepancies between their respective abilities to accumulate capital. (1)

When he presented this version in Havana, it received the acclaim of the delegates of the Latin American countries (Magariños 1991, 130). 
However, what was music to the ears of the delegates of Latin American countries would have displeased the industrial countries, especially the United States. This fact appears to have caused some consternation among UN high officials in New York, who were anxious to distance the UN from Prebisch's introduction. Accordingly, after the Havana conference was over, it was submitted to the secretary-general as an "essay" commissioned in the process of "fostering research." 44 It was then proposed to the UN publications committee to break the rule that authors of UN publications should not be identified by name. This course of action was designed to ensure that Prebisch took "credit (and responsibility) for the report ... in order to emphasize that the views expressed... were those of the author and not those of any UN organ." The proposal was presented "as an exceptional one, unlikely to recur but in the present circumstances very desirable." 45 Prebisch's suspicion that no international organization would feel comfortable with the viewpoint of the underdeveloped countries was thus confirmed.

The UN's tactic backfired. The Spanish original had been issued in May 1949, but, as Furtado has noted, it was some time before both this, and the English translation, were eventually published in New York by the United Nations, being circulated, as he put it, "with the slowness characteristic of official documents" (Furtado 1987, 80). Meanwhile, however, a Portuguese translation of the Spanish original, undertaken at Furtado's own urging, was published in Brazil in September 1949. It is at this point that the history of Prebisch's enormous influence began, spreading out from Brazil eventually to become worldwide. ${ }^{46}$ The publication of the English version of The Economic Development of Latin America and Its Principal Problems merely strengthened that effect in North America and Europe. In fact, this was how Singer now discovered the existence of Prebisch. "I believe it was between presenting my paper to the AEA in December 1949 and its publication in the summer

44. Gustavo Martínez Cabañas to Trygve Lie, 9 October 1949, letter of transmittal printed in Prebisch 1950.

45. H. E. Caustin to A. D. K. Owen, 12 October 1949, UN Archive, DAG-17 box 33; see also Magariños 1991, 129.

46. Its first incarnation was in Spanish, as UN document E/CN.12/89, dated 14 May 1949. It appeared in the July-September 1949 issue of El trimestre economico. At the instance of Furtado, it was published in Portuguese in the Revista Brasileira de economia in October 1949. It was republished in Spanish in Santiago in April 1950, and again in English later in 1950 in Lake Success, New York, as UN document no. E/CN.12/89/Rev.1. Its subsequent publication history until 1986 is to be found in United Nations 1987, 52. 
of 1950 that I discovered that Raúl Prebisch, my colleague at the UN, had developed very similar opinions and had also put the problem of poor terms of trade for primary products into the centre of thinking of the Economic Commission for Latin America" (Singer 1997, 141). The main result of identifying the author was that the polished and polemical Prebisch rapidly gained greater recognition in Europe and North America as a "UN economist" than did the more understated Singer, who had published under his own name only in academic journals.

\section{Prebisch's Contribution: The Economic Mechanics of Secular Decline}

Given the evidence outlined above, it seems clear that, if the PrebischSinger thesis is defined as the statement of the phenomenon of secular decline in the terms of trade of primary products, if anyone can be said to have anticipated Singer, it would be Kindleberger or Samuelson, rather than Prebisch. After all, both of them, unlike Prebisch, made explicit published remarks on the issue. Prebisch, however, made a contribution distinct from that made by Singer. This was to advance a cyclical-cumstructural mechanism to explain the decline, one more complicated than the purely structural interpretation of Singer.

Unlike the 1948 lectures, which singled out restrictions on labor immigration from countries not experiencing technical progress (type B), the new mechanism was based on institutional factors that permitted the retention of productivity gains by labor in countries where there was technical progress (type A). Prebisch $(1950,12)$ further argued, characteristically, that "the existence of this phenomenon cannot be understood, except in relation to trade cycles and the way in which they occur in the centres and at the periphery, since the cycle is the characteristic form of growth of the capitalist economy, and increased productivity is one of the main factors of that growth." He suggested that, even though in the boom primary product prices typically rise faster than industrial prices, deterioration in the commodity terms of trade of the periphery is nevertheless possible, if, in the slump, primary commodity prices decline steeply enough, compared with industrial prices. The explanation offered of why primary product prices declined severely in the slump compared with industrial prices was "the well-known resistance to a lowering of wages" at the center. By contrast, "the characteristic lack of organization among the workers employed in primary production 
prevents them from obtaining wage increases comparable to those of the industrial countries, and from maintaining the increases to the same extent" (13). 47

However, instead of leaving matters there, Prebisch also made another argument that seemed to undermine his first explanation. He identified industrial production and primary production with groups of countries, described as "center" and "periphery." He then argued that the differing strength of organized labor at the center and the periphery was not the crux of the matter, because even if workers at the periphery were able to resist wage decreases as strongly as industrial workers were, adjustment would take place by another process. The high prices of primary products would force a contraction of industrial production, which in turn would cut the demand for primary products. Recalling the experience of the Great Depression of the 1930s, Prebisch commented that "the forced readjustment of costs of primary production during the world crisis illustrates the intensity that this movement can attain" (13-14). This was the germ of the idea, later taken up by dependency and world system theorists, that the "center" was able to drain resources away from countries on the "periphery," regardless of their respective states of labor organization.

As has been seen, Prebisch had arrived at his explanation in April and May 1949. Prebisch and Singer probably arrived at their respective explanations of primary commodity terms of trade decline independently, although again Singer was first. Singer had presented his explanation, in embryonic form, in a paper originally presented in December 1948 and published in March 1949, then more fully in another paper to the American Economic Association conference in December 1949.48 This further paper explored factors that had "reduced the benefits to under-developed countries of foreign trade-cum-investment based on export specialization in food and raw materials." The first of these was that the secondary and cumulative effects of foreign export enclave investment were felt in the investing country, not the country where the investment was made. The second was that countries were "diverted" into types of economic

47. The dislocation to relative prices caused by monopolistic tendencies in the labor and manufactures markets of Europe had been the theme of Gustav Cassels's 1927 League of Nations study Recent Monopolistic Tendencies in Industry and Trade (Love 1991, 2).

48. The basic idea of a structural difference between countries where increased efficiency of production leads to higher incomes and those where it leads to falling product prices was already in Singer 1949, 2-3. 
activity that offered less scope for technical progress and internal and external economies. The third factor, "perhaps of even greater importance," was the movement of the terms of trade. Singer, while conceding that the statistics in Relative Prices (United Nations 1949c) were open to doubt and objection in detail, regarded the general story that they told as "unmistakable" (Singer [1950] 1975, 48).

Singer's proposed mechanism of secular decline was less complicated and based less on business cycles than Prebisch's. It was an asymmetric process whereby (1) the gains from technical progress in manufacturing are distributed to the producers in the form of higher incomes, while (2) the smaller gains from technical progress in primary commodity production are distributed to the consumers in the form of lower prices. On this basis, the industrialized countries have the best of both worlds, as producers of manufactures and as consumers of primary products. The underdeveloped countries have the worst of both worlds, as consumers of manufactures and as producers of primary products. Thus the benefits of foreign trade are shared unequally, and traditional foreign investment in plantations and mines did, after all, "form part of a system of "economic imperialism' and of 'exploitation," albeit not in the classical Marxist or Leninist sense (49-51).

Prebisch's interpretation of the secular decline, although possessed of its own ambiguities, gave an illusion of greater concreteness than Singer's. Instead of two sets of countries defined by the types of products that they exported and imported, Prebisch's concept of center and periphery seemed to have a spatial, even geographical, reality to it. His introduction of economic cycles into the mechanism allowed the short and medium term to be integrated with the long term, and countered the static quality of the purely structural approach. In general, this more complex schema opened the door to broader analyses of the economic conjuncture and policy recommendations on the issues of immediate concern to Latin American economists. Although fertile in these ways, Prebisch's interpretation itself was still very succinct, perhaps reflecting the novelty of the secular decline thesis even to him, and it therefore remained obscure on a number of crucial questions (Cardoso [1980] 1984, 27, 29-30; Furtado 1987, 66-67). It was also quite different from the theoretical model that Prebisch published in 1959, which resembled the standard neoclassical model of a small open economy, but with the exception of a small number of special assumptions (Prebisch 1959). 49

49. See the commentary in Flanders 1964 and FitzGerald 2000, 61-69. As FitzGerald indicates, there are two stages in Prebisch's explanation of terms of trade decline, the first based 
The ambiguities notwithstanding, Prebisch's "heresies," boldly laid out "a la Bernard Shaw" (as he put it), proved as appealing to the underdeveloped countries of Latin America as they were anathema to UN headquarters in New York (Magariños 1991, 129).

\section{Summary and Concluding Reflections}

The United Nations ECLA had been born against the wishes of the United States. In preparing for its first major conference it lacked the statistical infrastructure to discharge one of its primary tasks, to survey the common economic and technical problems of the region. This provided the cue for statistical help from UN headquarters in New York. During the preparations for the conference, Singer's work was transmitted to ECLA by three different channels between December 1948 and April 1949. An early version arrived in December 1948, but does not seem to have been followed up by Eugenio Castillo. The second transfer was via Martínez Cabañas and Coire to Prebisch before the latter arrived in Santiago, and this was the critical route. At Martínez Cabañas's prompting, Prebisch "latched onto the terms of trade idea," in the words of Victor Urquidi, 50 and meshed it with his own framework of thought in April/May 1949. The additional data he requested from New York (the third route) arrived too late to be useful. The document that became The Economic Development of Latin America and Its Principal Problems thus contained-as far as the terms of trade was concerned-merely a small part of the original UN study data, minimally reformulated.

Thus the conventional view, that Prebisch achieved priority over Singer in stating the thesis of secularly declining terms of trade for primary producers, is not based on an accurate chronology of ideas. The near simultaneity of the dates of the first English publications of the thesis by Prebisch and Singer cannot be relied upon as a means of dating the two men's contributions. The key events did not take place in 1950 at all, but in 1948 and 1949 in the run-up to and the aftermath of the ECLA conference at Havana. Prebisch's presentation to the Havana conference was a resounding success, turning him into a champion of the interests of the underdeveloped countries. Senior UN officials attempted to

on a neo-Ricardian model of price formation at the center and technical progress, and the 1959 version, in which there is no functional distribution or technical progress, just certain nonstandard characteristics of exogenous demand.

50. In an interview conducted by Tom Weiss for the UN Intellectual History Project. 
distance themselves from Prebisch by identifying him as the author of the views to which the developed countries took exception. In so doing, they unwittingly heightened his prestige.

The common belief that the thesis of the deterioration of the terms of trade was first picked up from Latin America by North American and European scholars during the 1950s is therefore inaccurate (Kay 1989, 8). What happened in the 1950s was in fact the transmission of the thesis back again. The more detailed chronology of events given here has also indicated a further unsatisfactory aspect of the conventional wisdom, namely, the general lack of precision about what constitutes the Prebisch-Singer thesis. Is it to be understood simply as a claim about a long-run downward trend in the terms of trade of primary producers, that is to say, the statistical phenomenon of secular decline? Or, is it the delineation of an economic mechanism that could account for a long-run secular decline? Or is it both? If the thesis is the empirical fact of a secular decline, it is clear that Singer had priority, and Prebisch's work was wholly derivative. If it is the specification of a theoretical mechanism to account for a secular decline, Singer also had priority, but Prebisch's contribution was independent - and also more elaborate, if convoluted.

In terms of the dissemination of these ideas, however, it is clear that Singer benefited from the existence of Prebisch as much as Prebisch had previously benefited from the existence of Singer. Let us ask what would have happened to the ideas of each, had the other been absent. If Singer had not overcome his personal reluctance to join the UN, Prebisch may well not have integrated declining terms of trade into his text. However, if Prebisch had gone to work for the IMF and not ECLA, the impact of Singer's study in Latin America might have amounted to no more than the very faint mark that it left on the 1948 Economic Survey. From the viewpoint of publicity and political repercussions, therefore, it was indeed the "Prebisch-Singer thesis."

The thesis promptly entered the Cold War battlefield. The initial U.S. response was an attempt to close down ECLA in 1951.51 Having failed, successive administrations slowly learned that Prebisch was in fact more pragmatic than he was polemical. By 1961, President Kennedy proposed

51. At the 1951 ECLA meeting in Mexico, a U.S. proposal to close the commission down was narrowly averted after Prebisch offered a stout defense of its work (and after a timely intervention from President Vargas of Brazil). See Magariños 1991, 138-141; Furtado 1987, 94; and "Progress Report Made by the Executive Secretary to the Fourth Session," UN document no. EC/CN.12/220, 29 May 1951. 
to the UN a "development decade" and launched the Alliance for Progress in the hope of a more constructive U.S. relationship with Latin America. Mr. M. V. Lavrichenko, deputy head of the Department of the USSR Ministry of Foreign Affairs, argued in the Second Committee of the General Assembly, that ECOSOC "should devote more of its attention to such urgent economic problems as the prevention of the economic plundering by the imperialist Powers of the countries of Asia, Africa and Latin America." In support of this claim, he reminded his listeners that "a United Nations survey published in 1949 concluded that, in the course of almost half a century, there had been a steady drop in the prices of raw materials in comparison with those of industrial goods." 52 Thus he demonstrated the long-lasting controversial power of the thesis that Prebisch and Singer had between them articulated, and that the United Nations had attempted to bury, yet inadvertently had ended up making world-famous.

\section{References}

Ahumada, J., and A. Nataf. 1950. Terms of Trade in Latin American Countries. IMF Staff Papers 1.1:123-35.

Bloch, H., and D. Sapsford. 1998. Prebisch and Singer Effects on the Terms of Trade between Primary Producers and Manufacturers. In Development Economics and Policy, edited by D. Sapsford and J. Chen. London: Macmillan.

Cardoso, F. H. [1980] 1984. Les idées à leur place. Paris: Éditions A. M. Métailié.

Dosman, E. J. 2001. Markets and the State: Theory and Practice in the Evolution of the "Prebisch Manifesto." Revista de la CEPAL/CEPAL Review, no. 75:87-102.

Ferrer, A. 1990. The Early Teachings of Raúl Prebisch. Revista de la CEPAL/CEPAL Review, no. 42:27-33.

FitzGerald, E. V. K. 1994. ECLA and the Formation of Latin American Economic Doctrine. In Latin America in the 1940s: War and Postwar Transitions, edited by D. Rock. Berkeley: University of California Press.

- 2000. ECLA and the Theory of Import Substituting Industrialization in Latin America. In Industrialization and State in Latin America: The Post-war Years, edited by E. Cardenas, J. A. Ocampo, and R. Thorp. London: Macmillan.

Flanders, M. J. 1964. Prebisch on Protectionism: An Evaluation. Economic Journal 74:305-26.

Furtado, C. 1987. La fantaisie organisée: Le développement est-il encore possible? Paris: Publisud.

52. Official Record of the UN General Assembly, sixteenth session, second committee, 720th meeting, 11 October 1961, pages 22-24. 
Haberler, G. 1988. International Trade and Economic Development. San Francisco: International Center for Economic Growth.

Hagemann, H., ed. 1997. Zur deutschsprachigen wirtschaftswissenschaftlichen Emigration nach 1933. Marburg: Metropolis-Verlag.

Harris, S. E., ed. 1943. Postwar Economic Problems. London: McGraw-Hill.

Kay, C. 1989. Latin American Theories of Development and Underdevelopment. London: Routledge.

Keynes, J. M. 1973-89. The Collected Writings of John Maynard Keynes. 30 vols. London: Macmillan.

Kindleberger, C. P. 1943a. International Monetary Stabilization. In Postwar Economic Problems, edited by S. E. Harris, 375-95. London: McGraw-Hill.

. 1943b. Planning for Foreign Investment. American Economic Review, Papers and Proceedings 33:347-54.

League of Nations. 1945. Industrialization and Foreign Trade. League of Nations Series II. Economic and Financial 1945.II.A.10.

Love, J. L. 1980. Raúl Prebisch and the Origins of the Doctrine of Unequal Exchange. Latin American Research Review 15.3:45-72.

. 1991. A New Look at the International Intellectual Environment of the Thirties and Forties. Hans Singer Papers in possession of John Toye, Prebisch box.

- 1994. Economic Ideas and Ideologies in Latin America since 1930. In Economy and Society, pt. 1 of Latin America since 1930: Economy, Society, and Politics. Vol. 6 of The Cambridge History of Latin America, edited by L. Bethell. Cambridge: Cambridge University Press.

Loveday, A. 1956. Reflections on International Administration. Oxford: Clarendon Press.

Magariños, M. 1991. Diálogos con Raúl Prebisch. Mexico: Banco Nacional de Commercio Exterior/Fondo de Cultura Económica.

Meier, G. M., and D. Seers, eds. 1984. Pioneers in Development. Washington, D.C.: The World Bank

Mitchell, W. C. 1927. Business Cycles. New York: National Bureau of Economic Research.

Osiatynski, J., ed. 1990-97. Collected Works of Michal Kalecki. 7 vols. Oxford: Oxford University Press.

Prebisch, R. 1945. Introducción al curso de economía política. Revista de ciencias económicas 33:525-37.

. 1946. Responsabilidad de los paises de la periferia. In Memoria: Primera reunion de técnicos sobre problemas de Banca Central del Continente Americano. Mexico City: Banco de México, S.A.

- 1948a. Apuntes de economía política (dinámica económica): Clases dictadas en el Curso Universitario de 1948. Buenos Aires: Faculty of Economic Sciences, University of Buenos Aires.

1948b. Dictamen del Dr. Raúl Prebisch acerca de los anteproyectos sobre Banco Central y bancos. Revista de hacienda 13.28:146-78. 
. 1950. The Economic Development of Latin America and Its Principal Problems. UN document no. E/CN.12/89/Rev.1. Lake Success, N.Y.: United Nations. 1959. Commercial Policy in Under-developed Countries. American Economic Review, Papers and Proceedings 492:251-73.

. [1934] 1991. La inflación escolástica y la moneda Argentina. In vol. 2 of Obras 1919-1948, 337-50. Buenos Aires: Fundación Raúl Prebisch.

. 1991. Obras 1919-1948. 3 vols. Buenos Aires: Fundación Raúl Prebisch.

Samuelson, P. 1948. International Trade and the Equalisation of Factor Prices. Economic Journal 58 (June):163-84.

Santa Cruz, H. 1995. The Creation of the United Nations and ECLAC. Revista de la CEPAL/CEPAL Review, no. 57:17-33.

Schellenberg, Walter. 2000. Invasion 1940: The Nazi Invasion Plan for Britain. London: St. Ermin's Press.

Schumpeter, J. 1939. Business Cycles: A Theoretical, Historical, and Statistical Analysis of the Capitalist Process. London: McGraw-Hill.

Simonsen, R. C. 1939. Brazil's Industrial Evolution. São Paulo: Escola Livre de Sociologia e Política.

Singer, H. W. 1949. Economic Progress in Underdeveloped Countries. Social Research: An International Quarterly of Political and Social Science 16.1:1-11.

— [1950] 1975. The Distribution of Gains between Investing and Borrowing Countries. In The Strategy of International Development: Essays in the Economics of Backwardness. London: Macmillan.

1984. The Terms of Trade Controversy and the Evolution of Soft Financing: Early Years in the UN. In Pioneers in Development, edited by G. M. Meier and D. Seers. Washington, D.C.: The World Bank.

. 1991. Comment by Hans Singer on "Raúl Prebisch, 1901-1971: The Continuing Quest," by Edgar J. Dosman and David H. Pollock. Hans Singer Papers in possession of John Toye, Prebisch box.

1997. The Influence of Schumpeter and Keynes on the Development of a Development Economist. In Zur deutschsprachigen wirtschaftswissenschaftlichen Emigration nach 1933, edited by H. Hagemann. Marburg: Metropolis-Verlag.

Spraos, J. 1980. The Statistical Debate on the Net Barter Terms of Trade between Primary Commodities and Manufactures. Economic Journal 90:107-28.

Thorp, R. 1998. Progress, Poverty, and Exclusion: An Economic History of Latin America in the 20th Century. Baltimore: Johns Hopkins University Press.

Toye, J. 2000. Keynes on Population. Oxford: Oxford University Press.

United Nations. 1949a. Economic Survey of Latin America 1948. UN document no. E/CN.12/82. Lake Success, N.Y.: UN Department of Economic Affairs.

. 1949b. Post-war Price Relations in Trade between Under-developed and Industrialized Countries. UN document no. E/CN.1/Sub.3/W.5. Lake Success, N.Y.: UN Department of Economic Affairs. 
1949c. Relative Prices of Exports and Imports of Under-developed Countries. Lake Success, N.Y.: UN Department of Economic Affairs.

1949d. Report to the Economic and Employment Commission on the Third Session of the Sub-Commission Held from 21 March to 11 April 1949. UN document no. E/CN.1/65. Lake Success, N.Y.: Sub-Commission on Economic Development.

. 1951. Economic Survey of Latin America 1949. UN document no. E/CN.12/164/Rev.1. New York: United Nations Department of Economic Affairs. 1987. Raúl Prebisch: Un aporte al estudio de su pensiamento. UN document no. LC/G.1461. Santiago de Chile: CEPAL.

Viner, J. 1952. International Trade and Economic Development. Oxford: Oxford University Press.

Whitaker, A. P., ed. 1945. Inter-American Affairs 1944. New York: Columbia University Press. 